\title{
METHOD DEVELOPMENT AND VALIDATION OF LOPINAVIR IN TABLET DOSAGE FORM USING REVERSED-PHASE HIGH-PERFORMANCE LIQUID CHROMATOGRAPHY
}

\author{
SUNKARA NAMRATHA ${ }^{1}$, VIJAYALAKSHMI A $^{2 *}$ \\ ${ }^{1}$ Department of Analysis, Bharat Group of Institutions, Ibrahimpatnam, Hyderabad, India. ${ }^{2}$ School of Pharmaceutical Sciences, Vels \\ Institute of Science, Technology and Advanced Studies, Pallavaram, Chennai, Tamil Nadu, India. Email: avijibaskaran@gmail.com
}

Received: 10 October 2018, Revised and Accepted: 11 December 2018

\section{ABSTRACT}

Objective: Reversed-phase high-performance liquid chromatographic method (RP-HPLC) was developed for the assessment of lopinavir in the dosage form of tablet.

Methods: Chromatogram was run through using Kromosil $\mathrm{C}_{18} 4.5 \times 150 \mathrm{~mm}$ using a mobile phase methanol: water of ratio $65: 35 \% \mathrm{v} / \mathrm{v}$ with a rate of flow of $0.8 \mathrm{ml} / \mathrm{min}$, measured by UV spectrometric detection at $265 \mathrm{~nm}$. The method developed was validated in terms of precision, accuracy, linearity, and robustness parameters.

Results: Retention time of lopinavir established at $2.482 \mathrm{~min}$ and percentage R.S.D of lopinavir found to be $1.0 \%$ and $0.5 \%$, respectively. The method shows that good linearity range of 30-150 $\mu$ g correlation coefficient of lopinavir was 0.997 . The limit of detection was 2.97 and limit of quantification was 9.92 , respectively. The percent purity of lopinavir was $99.87 \%$.

Conclusion: The suggested method (Rp-HPLC) for concurrent assay lopinavir was validated, which is appropriate method for the analysis of lopinavir quantitatively in tablet dosage forms and bulk.

Key words: Validation, Method development, Lopinavir, Reversed-phase high-performance liquid chromatography.

(C) 2018 The Authors. Published by Innovare Academic Sciences Pvt Ltd. This is an open access article under the CC BY license (http://creativecommons. org/licenses/by/4. 0/) DOI: http://dx.doi.org/10.22159/ajpcr.2018.v11s4.31715

\section{INTRODUCTION}

The selected drug lopinavir is a white to light (tan) powder, in water practically insoluble, but in methanol, it is freely soluble [1]. It is an antiHIV, anti-infective, and antiretroviral agents [2]. Lopinavir inhibits the HIV viral protease enzyme. Detailed literature survey for the lopinavir determination in formulations and bulk drug revealed several methods that have been reported for the assay of it either alone or in combined dosage forms such as high-performance liquid chromatography (HPLC) [3-11] and UV spectrophotometric methods [12-17].

The development and validation of an analytical method is to ensure a specific, accurate, and precise method for a particular drug with an objective to enhance the conditions and parameters. From the literature survey that the reversed-phase HPLC (RP-HPLC) methods were not reported in the estimation of lopinavir. Thus, the present research paper describes the assessment of lopinavir by RP-HPLC method in tablet dosage form.

\section{MATERIALS AND METHODS}

\section{Materials and instrumentation}

Waters, separation module 2695, PDA detector Instrument with Kromosil $C_{18}$ column $4.5 \times 150 \mathrm{~mm}$ and HPLC - auto sampler - UV detector using Empower software version-2 and Lab India U.V double beam spectrometer of UV 3000+ model and U.V win software were used. HPLC grade water, methanol, acetonitrile, orthophosphoric acid, and $\mathrm{KH}_{2} \mathrm{PO}_{4} \mathrm{~K}_{2} \mathrm{HPO}_{4}$ were procured from Merck Enterprises, India.

\section{Lead of solutions and reagents}

Standard solution preparation

About $10 \mathrm{mg}$ of standard sample was weighed accurately, added to a volumetric flask of $10 \mathrm{ml}$ capacity, and added $7 \mathrm{ml}$ of diluents, dissolved completely by sonication and with stock solution the volume made up to the mark. To a volumetric flask of $10 \mathrm{ml}$ capacity, $0.9 \mathrm{ml}$ of stock solution was added and the solution was diluted to the mark using diluents.

\section{Preparation of sample solution}

To a $10 \mathrm{ml}$ volumetric flask added accurately weighed $10 \mathrm{mg}$ equivalent of lopinavir capsule powder, $1 \mathrm{ml}$ of diluents was added, dissolved completely by sonication and with stock solution the volume made up to the mark. $1 \mathrm{ml}$ of the prepared stock solution stated above was added to a volumetric flask of $10 \mathrm{ml}$ capacity, and using diluents, the solution was diluted up to the mark.

\section{Methodology}

The chromatographic system was injected with about $20 \mu \mathrm{L}$ of the blank solution, sample solution, and standard solution each, and lopinavir peak area was calculated.

\section{Process validation}

The proposed HPLC process validated in accordance of the ICH guidelines with aspect to accuracy, linearity, precision, specificity, limit of quantification (LOQ), robustness, and limit of detection (LOD) [10].

\section{Linearity}

The standard stock solution for both the drugs prepared individually by diluting to obtain the five standard solutions in the concentration of linearity range of $30-150 \mu \mathrm{g}$ for lopinavir. About $20 \mu \mathrm{l}$ volume was injected and run under above referred chromatographic conditions. From the values of peak area versus the concentration $(\mu \mathrm{g} / \mathrm{ml})$, linear regressions of lopinavir were executed. Linearity was checked with correlation coefficient and calibration curve. 


\section{Accuracy}

The fidelity method was committed in solutions made of various concentrations of lopinavir, that is, $50 \%, 100 \%$, and $150 \%$, the quantity of sample lopinavir is kept constant and amount of pure drug was varied in terms such as $5 \mathrm{mg}, 10 \mathrm{mg}$, and $15 \mathrm{mg}$ in case of lopinavir, i.e., $50 \%, 100 \%$, and $150 \%$, respectively.

\section{Repeatability, LOD, and LOQ [4,7]}

Assay preparation on same day during intraday precision (repeatability) was resolved by replicate analysis $(\mathrm{n}=3)$; intermediate precision was checked on 3 consecutive days for replicate analysis of the given solutions. Assay precisions were conveyed as relative standard deviation.

The following equation indicates the LOD from the calibration curve $[3,7]$.

$$
\text { LOD }=3.3 \times \frac{\mathrm{D}}{\mathrm{S}}
$$

Hence, y-intercept gives standard deviation and S is slope of line.

The LOQ was calculated as follows $[3,7]$ :

$$
\mathrm{LOQ}=10 \times \frac{\mathrm{D}}{\mathrm{S}}
$$

LOD and LOQ concentrations of test solution were injected 6 times in the chromatograph and R.S.D. percent was measured from the peak area of replicate injections.

\section{Robustness}

The precision study was performed for five injections of lopinavir. Each standard injection was injected in to chromatographic system.

The area of each Standard injection was used for calculation of \% RSD.

As the part of the method validation robustness, the impact of flow rate change deliberately and the mobile phase composition change with the method was evaluated [4].

a. Lopinavir standard solution $90 \mathrm{ppm}$ was prepared and by varying flow rates $(0.8-1.2 \mathrm{ml} / \mathrm{min})$ along with flow rate method analyzed [6].

b. Lopinavir standard solution $90 \mathrm{ppm}$ was prepared and analyzed by varying mobile phase composition from $75 \%$ to $55 \%$ along with the actual mobile phase.

\section{System suitability}

To $10 \mathrm{ml}$ volumetric flask added $10 \mathrm{mg}$ of lopinavir standard sample by weighing accurately and sonicated by adding $7 \mathrm{ml}$ of diluent, using stock solution, the volume makes up to the mark. To volumetric flask of $10 \mathrm{ml}$ capacity added $0.9 \mathrm{ml}$ lopinavir from the above stock solution, and using diluent, the solutions were diluted up to the mark.

\section{RESULTS AND DISCUSSION}

The suggested method originated as mere, specific, precise, and accurate for the routine estimation of drugs simultaneously. Several mobile phases with dissimilar solvents in varied proportions tried to resolve the drug peaks with fair peak asymmetry, resolution, and number of theoretical plates. Finally, a mobile phase consisting of $65: 35 \%$ v/v methanol: water was selected for analysis, which showed good resolution of lopinavir peak with a retention time of $2.482 \mathrm{~min}$, and neither of the impurities was interfering in its assay. System suitability trails were accomplished to specify resolution, column (Fig. 1) efficacy, peak asymmetry, and tailing factor. For the proposed method, all the system suitability criteria were within the limits specified and findings are stated in Table 1.

\section{Linearity}

The correlation coefficient was calculated by plotting a graph with concentration in the X-axis and Y-axis peak area. It was found to be 0.999 . Correlation coefficients, slopes, and y-intercepts of regression lines for the two substances were evaluated and results are incorporated in Table 2.

\section{Accuracy}

The percent recovery of lopinavir ranged out of 98.0-102.0\%, respectively. Therefore, no interference from the additives commonly present in the tablets and developed technique constitute to be precise as the percent relative standard deviations for repeatability and intermediate precision is $<2$ as per proposed ICH guidelines. The value of $1.0 \%$ for lopinavir indicates good repeatability of the method. The recovery studies data are stated in Table 3.

\section{$L O D$ and $L O Q$}

LOD for lopinavir was 2.97 and LOQ for lopinavir is $9.92 \mathrm{~g} / \mathrm{mL}$ and $10.02 \mathrm{~g} / \mathrm{mL}$, respectively.

\section{Precision}

The \%RSD of Lopinavir was found to be 0.15 (Table 4). \%RSD values of peak area found to be less than 2.0. Hence the optimized method was found to be precise as per ICH guidelines Q2 (R1).

\section{Robustness}

The robustness considerate varied chromatographic conditions, the retention time and peak asymmetry of the two drug peaks were not significantly influenced by the low standard deviation values (below 2) for each criterion. Thus, the developed LC method was robust in the findings of lopinavir in combined tablet dosage formulations Table 5 .

\section{System suitability}

Accurate amount of $10 \mathrm{mg}$ lopinavir standard was weighed and the standard drug was transferred to volumetric flask of $10 \mathrm{ml}$ capacity, sonicated after adding diluent of about $7 \mathrm{ml}$ to dissolve the components and stock solution added to make volume up to the mark. Pipetted $0.9 \mathrm{ml}$ of the prepared stock solution stated above to standard flask of $10 \mathrm{ml}$ capacity and diluted using diluent up to the mark.

\section{Assay}

The proposed technique was applied in terms of assay for commercial formulation by injecting the blank solution, standard solution, and sample solution of $20 \mu \mathrm{L}$ each into the chromatographic system. The percentage of lopinavir was calculated from the peak areas. The percent purity of lopinavir was found to be $99.87 \%$. The assay findings and label

Table 1: System suitability parameters for lopinavir

\begin{tabular}{ll}
\hline System suitability parameter & Lopinavir \\
\hline Retention time (min) (mean \pm S.D., $n=5)$ & 2.428 \\
Tailing factor (peak asymmetry) & 0.87 \\
Theoretical plates & 4024 \\
\hline
\end{tabular}

Table 2: Calibration data of lopinavir

\begin{tabular}{lll}
\hline Name & Rt & Area \\
\hline Lopinavir & 2.428 & $1,608,152$ \\
Lopinavir & 2.422 & $2,592,905$ \\
Lopinavir & 2.430 & $3,778,327$ \\
Lopinavir & 2.426 & $5,170,038$ \\
Lopinavir & 2.433 & $6,249,400$ \\
Coefficient of correlation (R2) & & 0.997 \\
\hline
\end{tabular}




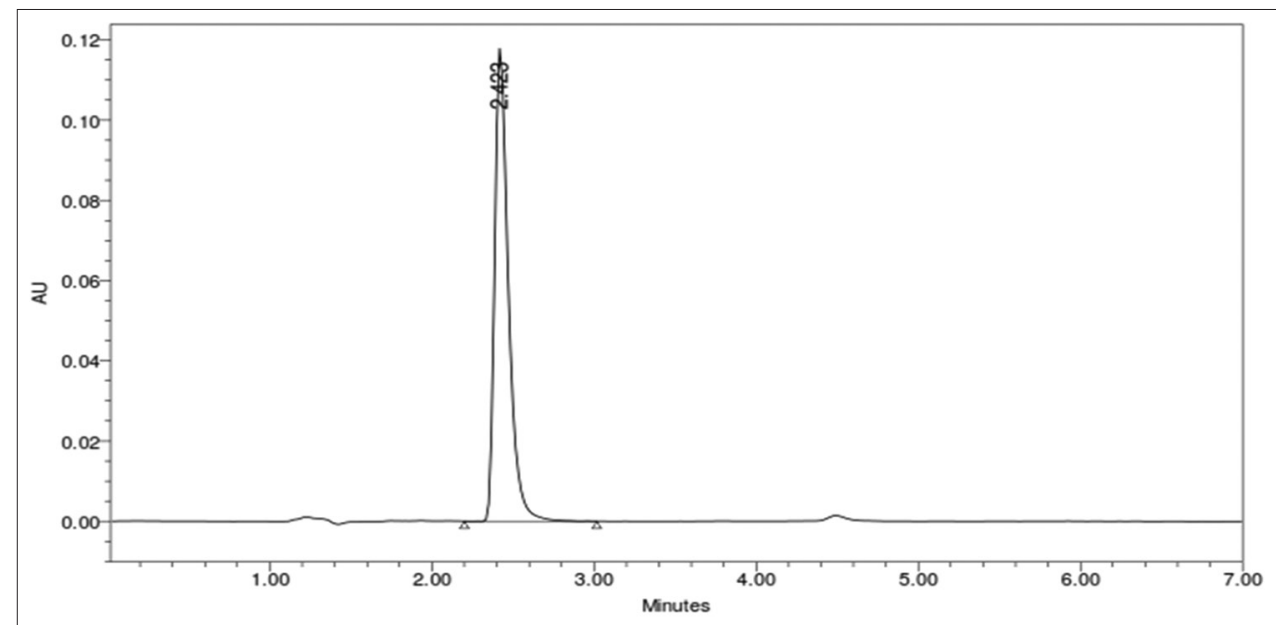

Fig. 1: Typical high-performance liquid chromatography chromatogram of lopinavir

Table 3: Accuracy of lopinavir

\begin{tabular}{llllll}
\hline $\begin{array}{l}\text { \% concentration } \\
\text { (at specification level) }\end{array}$ & $\begin{array}{l}\text { Average } \\
\text { area }\end{array}$ & $\begin{array}{l}\text { Amount } \\
\text { added (mg) }\end{array}$ & $\begin{array}{l}\text { Amount } \\
\text { found (mg) }\end{array}$ & \% recovery & $\begin{array}{l}\text { Mean } \\
\text { recovery }\end{array}$ \\
\hline 50 & $1,048,287$ & 5 & 5.14 & 100.2 & $100.4 \%$ \\
100 & $1,378,200$ & 10 & 10.01 & 98.8 & \\
150 & $1,715,480$ & 15 & 15.2 & 96.5 & \\
\hline
\end{tabular}

Table 4: Precision of lopinavir

\begin{tabular}{llll}
\hline \multicolumn{2}{l}{ Name: LOPINAVIR } & & \\
\hline S. No & Name & Rt & Area \\
\hline 1 & LOPINAVIR & 2.423 & 693,078 \\
2 & LOPINAVIR & 2.424 & 693,338 \\
3 & LOPINAVIR & 2.424 & 695,080 \\
4 & LOPINAVIR & 2.424 & 694,843 \\
5 & LOPINAVIR & 2.423 & 695,336 \\
Mean & & & 694,335 \\
SD & & & 1047.5 \\
\% R.S.D. & & & 0.15 \\
\hline
\end{tabular}

Table 5: Robustness studies for lopinavir

\begin{tabular}{llll}
\hline S. No & Flow rate (ml/min) & \multicolumn{2}{c}{ System suitability results } \\
\cline { 3 - 4 } & & USP plate count & USP tailing \\
\hline 1 & 0.8 & 4352 & 1.1 \\
2 & 1 & 4024 & 1.2 \\
3 & 1.2 & 3730 & 1.2 \\
\hline
\end{tabular}

Table 6: System suitability parameters for lopinavir

\begin{tabular}{llll}
\hline S. No & $\begin{array}{l}\text { Change in organic composition } \\
\text { in the mobile phase }\end{array}$ & $\begin{array}{l}\text { System suitability } \\
\text { results }\end{array}$ \\
\cline { 3 - 4 } & & $\begin{array}{l}\text { USP plate } \\
\text { count }\end{array}$ & $\begin{array}{l}\text { USP } \\
\text { tailing }\end{array}$ \\
\hline & & 4331 & 1.20 \\
& & 4024 & 0.87 \\
2 & *Actual & 3693 & 1.26 \\
\hline
\end{tabular}

claim of the substance had good agreement between them. This implies the disposition of drug in tablet dosage form was steady without significant variation. The result of estimation is presented in Table 6.

\section{Result analysis of tablet formulation}

Liquid chromatographic method was developed in this study determine the lopinavir amount in combined tablet dosage forms. The total chromatographic analysis time per sample was $5 \mathrm{~min}$ with respect to the lopinavir retention time established at $2.482 \mathrm{~min}$ and percentage R.S.D. of lopinavir found to be $1.0 \%$ and $0.5 \%$, respectively.

\section{CONCLUSION}

For concurrent assay of lopinavir, method suggested (RP-HPLC) was validated and it was an appropriate method for routine analysis of lopinavir quantitatively in dosage forms and. The proposed technique is accurate, rapid, and sensitive. It makes the use of little quantities of solvents and changes the set of conditions requires in short intervals. It does not suffer from any hindrance due to common additives present in pharmaceutical dosage forms and can be readily accepted for quality control analysis.

\section{ACKNOWLEDGMENT}

Authors hereby acknowledge sincere thanks to the management for providing the amenities during our research work.

\section{REFERENCES}

1. Indian Pharmacopoeia Commission. Indian Pharmacopeia. Vol. 1. Ghaziabad (India): Indian Pharmacopoeia Commission; 2007. p. 715.

2. British Pharmacopoeia Commission. British Pharmacopeia. Vol. 1. Lincoln (UK): London Stationary Office; 2007. p. 136.

3. Sharma BK. Instrumental Method of Chemical Analysis. 24 $4^{\text {th }}$ ed. Meerut: GOEL Publishing House; 2005. p. 46-68.

4. Chatwal GR Anand KS. Instrumental Methods of Chemical Analysis. $5^{\text {th }}$ ed. Mumbai: Himalaya Publishing House; 2002. p. 149.

5. Munson JW. Modern Methods of Pharmaceutical Analysis. Mumbai: Medical Book Distributors; 2001. p. 17-54.

6. Willard HH, Merritt LL, Dean JA Settle FA. Instrumental Methods of Analysis. $7^{\text {th }}$ ed. New Delhi: CBS Publishers and Distributors; 1988. p. 436-9.

7. Synder KL, Kriklad JJ Glajch JL. Practical HPLC Method Development. $2^{\text {nd }}$ ed. USA: Wiley-Interscience Publication; 1983. p. 1-10.

8. Ponnilavarasan I, Rajasekaran A, Dharuman JG, Kalaiyarasi D, 
Senthilkumar M. RP-HPLC method for simultaneous estimation of antiretroviral drugs lopinavir and ritonavir in tablet dosage form, digest. J Nanomater Biostruct 2010;5:771-8.

9. Phechkrajang CM, Thin EE, Sratthaphut L, Nacapricha D, Wilairat P. Quantitative determination of lopinavir and ritonavir in syrup preparation by liquid chromatography. J Pharm Sci 2009;36:1-12.

10. Temghare GA, Shetye SS, Joshi SS. Rapid and sensitive method for quantitative determination of lopinavir and ritonavir in human plasma by liquid chromatographytandem mass specrtometry. E J Chem 2009;6:223-30.

11. Myasein F, Kim E, Zhang J, Wu H, El-Shourbagy TA. Rapid, simultaneous determination of lopinavir and ritonavir in human plasma by stacking protein precipitations and salting-out assisted liquid/liquid extraction, and ultrafast LC-MS/MS. Anal Chim Acta 2009;651:112-6.

12. Bentley AO, Driver JE. Text book of Pharmaceutical Chemistry. $8^{\text {th }}$ ed.
New York: O’Brein Oxford University Press; 1985. p. 1-3.

13. International Conference on Harmonization. Validation of Analytical Procedures Methodology-14. Federal Register; 1996. p. 1-8

14. Suneetha A, Kathirvel S, Ramachandrika G. A validated Rp-HPLC method for simultaneous estimation of lopinavir and ritonavir in combined dosage form. Int J Pharm Pharm Sci 2011;3:49-51.

15. Nagulwar VP, Bhusari KP. Simultaneous estimation of ritonavir and lopinavir by absorption ratio (Q-analysis) UV spectrophotometric method in combined tablet dosage form. Pharm Lett 2010;2:196-200.

16. Thakkar HP Patel KH. A first derivative spectrophotometric method for the estimation of lopinavir in tablets. Chron Young Sci 2010;1:22-5.

17. Vaishali N, Kishore B. Simultaneous estimation of ritonavir and lopinavir by vierodt's UV spectrophotometric method in combined tablet dosage form. Int J Pharm Sci 2010;2:533-6. 